This Journal is available in Telkom University online Journals

Jurnal Manajemen Indonesia

\title{
Entrepreneurial Behavior among Undergraduate Business, Social and Engineering Students: A Case Study of a Private Indonesian University
}

\author{
Anggraeni Permatasari ${ }^{1}$, Arisda Agustina ${ }^{2}$ \\ ${ }^{1}$ President University, Faculty of Business, Bekasi, Indonesia \\ ${ }^{2}$ President University, Faculty of Business, Bekasi, Indonesia
}

\begin{abstract}
Most universities or higher education institutions in Indonesia are developing an effective program supporting their students in becoming become entrepreneurs. They believe that entrepreneurial behaviour can be developed through entrepreneurship education. Therefore, these universities continually improve their entrepreneurship curricula by integrating both theoretical concepts of entrepreneurship and practical contexts within such education. The purpose of the research reported here is to compare the effects of personality trait dimensions on students' entrepreneurial ambitions and their behaviour. The study used personality trait dimensions such as: internal locus of control, need for achievement, tolerance of risk and entrepreneurial awareness as independent variables. Quantitative methods, including Structural Equation Modelling (SEM), were applied for the purposes of data analysis. The research populations consisted of final year undergraduate students who had already undergone an entrepreneurship learning program in Indonesia. Data collection employed questionnaires distributed to undergraduate students drawn from three different faculties: Business Studies, Social Studies and Engineering at private universities. The measurement instrument consisted of a Likert scale 1-7. The results demonstrated that private university sector entrepreneurial education, by enhancing certain personality traits, has significant effects on the entrepreneurial behaviour of students. The research findings can be used to monitor and evaluate the entrepreneurial learning process within higher education. The implications can be used for policy makers and educators to add value at the design stage of entrepreneurship course syllabi within higher education institutions.
\end{abstract}

Keywords- Entrepreneurship Education, Higher Entrepreneurial Institution, Students Entrepreneurial Behaviour, Entrepreneurial Intention, Personality Traits, Indonesia Education

\begin{abstract}
Abstrak
Sebagian besar perguruan tinggi di Indonesia sedang mengembangkan program kewirausahaan yang efektif untuk menciptakan pengusaha. Perguruan tinggi percaya bahwa perilaku kewirausahaan dapat dikembangkan melalui program pendidikan kewirausahaan Oleh karena itu, perguruan tinggi mengintegrasikan konsep teoritis dan konteks praktis ke dalam pengembangan kurikulum kewirausahaannya. Penelitian ini bertujuan untuk mengetahui pengaruh dimensi kepribadian terhadap minat dan perilaku kewirausahaan mahasiswa pada salah satu perguruan tinggi swasta di Indonesia. Populasi dalam penelitian ini adalah mahasiswa tingkat akhir yang telah mengikuti program kewirausahaan. Pengumpulan data menggunakan kuesioner yang disebarkan kepada mahasiswa program sarjana dari tiga fakultas yang berbeda, yaitu studi bisnis, ilmu Sosial dan teknik, setelah itu data dianalisa menggunakan Structural Equation Modeling (SEM). Hasil penelitian menunjukkan bahwa pendidikan wirausaha yang menekankan pada sifat kepribadian wirausaha terbukti memiliki pengaruh signifikan terhadap perilaku kewirausahaan siswa. Temuan penelitian ini dapat digunakan untuk memonitor dan mengevaluasi proses belajar mengajar kewirausahaan pada perguruan tinggi di Indonesia.

Kata kunci- Pendidikan Kewirausahaan, Perguruan Tinggi Wirausaha, Perilaku Wirausaha, Minat Wirausaha Mahasiswa, Sifat Kepribadian
\end{abstract}

\section{Article info}

Received (21 ${ }^{\text {st }}$ February, 2018)

Revised (15 ${ }^{\text {th }}$ March, 2018)

Accepted (19 ${ }^{\text {th }}$ March, 2018)

Corresponding_author: anggraeni@president.ac.id 


\section{INTRODUCTION}

Entrepreneurs have positively contributed to the economic growth and social development of a wide range of countries. "Entrepreneurship and innovation have been recognized as the critical drivers of sustainable economic development and competitive advantage" (Kassean et al., 2015; Amband \& Damit, 2015). "Entrepreneurship is a driving force within the economy" (Hayes \& Richmond, 2017). Entrepreneurship is not only about devising business plans and setting up new businesses, but also about how to be creative, innovative, and supportive of growth (Yurtkoru, Kuşcu \& Doğanay, 2014; Yildirim, Çakir, \& Askun, 2016).

In 2014, the number of entrepreneurs in Indonesia increased to $1.65 \%$ of its population of 238 million people. However, this was still insufficient to meet the optimum minimum level of entrepreneurship of $2 \%$ for a country (McCleland, 1965). According to the Global Entrepreneurship and Development Index (GEDI, 2017), Indonesia ranks $90^{\text {th }}$ out of 138 countries, with a GEDI score of 21.2. This is due to a higher number of entrepreneurs in certain countries such as the USA which ranks first with a GEDI score of 83.4, Singapore ranks $24^{\text {th }}$ with a GEDI score of 52.2 and Malaysia $54^{\text {th }}$ with a GEDI score of 33.4 , while Thailand ranks $65^{\text {th }}$. with a GEDI score of 27.1. Based on the contents of Table 1, Indonesia requires more entrepreneurs in order to compete with other countries. Therefore, to increase the number of Indonesian entrepreneurs, the Ministry of National Education introduced entrepreneurship courses into higher education curricula.

Table 1. Global Entrepreneurship \& Development Index Rankings

\begin{tabular}{|c|c|c|c|}
\hline Rank & Country & $\begin{array}{c}\text { GDP Per Capita Internationa } \\
\text { \$(WB) }\end{array}$ & GEI Score \\
\hline 1 & United States & 52,676 & 83.4 \\
\hline 7 & Australia & 42,149 & 72.5 \\
\hline 8 & United Kingdom & 37,451 & 73.1 \\
\hline 24 & Singapore & 56,264 & 52.2 \\
\hline 25 & Japan & 35,653 & 51.7 \\
\hline 48 & China & 12,559 & 36.3 \\
\hline 54 & Malaysia & 23,644 & 33.4 \\
\hline 65 & Thailand & 14,185 & 27.1 \\
\hline 90 & Indonesia & 9,725 & 21.2 \\
\hline
\end{tabular}

Sources: GEDI, 2017

Nowadays, most countries are more concerned with entrepreneurship education in higher education which has significantly increased students' intention to become entrepreneurs or establish their own businesses (Karabulut, 2016; Yildirim, Çakir, \& Askun, 2016). Entrepreneurship education programs foster and support entrepreneurial skills and activities. "The development of entrepreneurial education approaches to teaching, learning and support practices suggests that the delivery of any desired entrepreneurial outcome, challenges institutions and educators to review and reflect on what needs to be taught and learnt" (Ghina, Simatupang \& Gustomo, 2017).

Entrepreneurship programs also help students to become experienced and act like professional entrepreneurs. Effective entrepreneurship education influences the ability to earn a high income, while reducing unemployment levels (Din, Anuar \& Usman, 2015). The goal of an entrepreneurship education program is to support students and undergraduate students of the university in setting up their own businesses. Potishuk \& Kratzer (2017) stated that, "Entrepreneurship education plays an important role in fostering and promoting entrepreneurship activity". The university believes that graduates can help the government to increase economic growth and reduce social problems, including unemployment, by establishing their own businesses. This research's novel aspect consists of the use of empirical evidence of entrepreneurial behavior on the part of students from different faculties encompassing Business Studies, Social Studies and Engineering. Therefore, the purpose of this research is to examine the effect of personality traits on student entrepreneurial behavior, mediating by the entrepreneurial objectives of private universities within Indonesia. 


\section{LITERATURE REVIEW}

\section{A. Entrepreneurial Behaviour}

Much of the literature on entrepreneurship argues that entrepreneurial activity is related to entrepreneurial behavior described as characteristic of the values and needs of a person with true motivation and determination to participate (Kirkley, 2016). Küttim et al. (2014) stated that entrepreneurial behavior consists of the activities of a person who is driven to create a new product and introduce it to the marketplace where behavior is influenced by factors including: age, gender, experience, positive attitude and subjective norms. Entrepreneurial behaviour plays a significant role in the development of social skills which are, at least, as important as hard skills. "Entrepreneurial behaviour is an individual's dynamic set of beliefs in his ability to competently perform a particular task or set of activities" (Kassean et al., 2015). This set of beliefs also drives entrepreneurs to acquire knowledge, skills and experience in order to participate in the entrepreneurial process. Values such as self-sufficiency and confidence are core values that entrepreneurs must possess in order to prosper in business (Din, Anuar \& Usman, 2015). Therefore, within this research, entrepreneurial behavior refers to the values underpinning an individual's ability to succeed in establishing a business based on his/her personal decisions and entrepreneurial skills.

\section{B. Entrepreneurial Intention}

Entrepreneurial intention is rooted in the vision, dreams and emotions of entrepreneurs and refers to a person's interest in striving to develop his/her own business and demonstrating the behaviour stemming from this desire (Koe, Sa'ari, Majid, Ismail, 2012; Koe, Omar, Sa'ari, 2014). Entrepreneurial intention can also be defined as the range of activities that involve the discovery, evaluation and exploitation of opportunities in creating new products and services, and introducing them to the market in unprecedented ways (Yurtkoru, Kuscu \& Doganay, 2014). Entrepreneurial intention represents the motivation of an individual to be a professional entrepreneur. Rauch \& Frese (2007) in Brandstätter (2011) believe that, "The locus of control, propensity to take risks, self-efficacy, need for achievement, tolerance of ambiguity and innovativeness are psychological characteristics associated with entrepreneurship". Therefore, entrepreneurial intention can be concluded to be the heartfelt commitment of a person with the courage and the desire to enter a field of business through creative, innovative ideas to then plan, organize, accept risk and develop the resulting enterprise to achieve the goal. An entrepreneur is required to be able to see the opportunities that exist and be capable of exploiting them through hard work and high spirits.

\section{Personality Traits}

\section{Locus of Control (LoC)}

The Locus of Control (LoC) constitutes the set of beliefs that determine people's behavior. LoC represents the extent to which an individual assumes responsibility for the success or failure of his/her life (Khan, 2013; Karabulut, 2016). Entrepreneurship studies spotlight the importance of exploring certain personality traits that could be linked to entrepreneurial tasks such as the internal LoC. Therefore, people who possess higher internal LoC will accept risks and establish businesses (Karabulut, 2016).

LoC is a personality characteristic related to the level of emotional control. Therefore, people who register high scores on emotional control have clear visions of the future. Many studies have shown that entrepreneurs have higher LoC than other people. Karabulut (2016) stated that the internal locus of control, a need for achievement, risk tolerance and entrepreneurial alertness are all personality trait dimensions which lead a person to develop entrepreneurial aspirations. When the internal LoC of people is stronger, entrepreneurial intention is greater (Kristiansen \& Indarti, 2004).

\section{Need for Achievement}

Need for achievement can be defined as the determination to perform to a high standard and record significant achievements and is known to be an entrepreneurial trait that greatly influences the success of a company. "The importance of studying this specific deep-level characteristic arises from the high level of ambiguity and uncertainty associated with an entrepreneurial scenario, where decisions of entrepreneurs constitute the pivotal source of authority" (Khan, 2013). Individuals who score higher on the need for achievement scale are interested in working in situations over which they have more control. Consequently, 
individuals concerned with the need for achievement would be inclined towards entrepreneurship, based on the supposition that individuals are more attracted to roles that are compatible with their personalities.

\section{Risk Tolerance}

Risk tolerance consists of, "The willingness of strategic decision-makers to invest resources in projects with uncertain outcomes" (Yildirim, Cakir \& Askun, 2016). Passion is an important trigger of innovativeness, proactiveness and risk-taking which is consistent in nature. The possibility that an entrepreneur's commitment to commercial growth helps overcome challenges in the initial stage of a company's development is a factor that has previously been commented on. First, because of the size of the commercial enterprise, entrepreneurs exert a strong influence on its behavior, Second, entrepreneurs have a single, hierarchically dominant identity. Therefore, they may disengage from activities relevant to other less meaningful identities. Risk tolerance exerts positive, moderate influences on entrepreneurial intentions (Yurtkoru et al., 2014). According to Yutkore et al., universities are required to play a more specific and active role in implementing educational, research and resource programs on entrepreneurship with regard to risk-taking behaviors and entrepreneurial intentions.

\section{Entrepreneurial Alertness}

Entrepreneurial alertness is a major trait of entrepreneurs. "Entrepreneurial alertness is a distinctive set of perceptual and information-processing skills which has been advanced as the cognitive engine driving the opportunity identification process." (Gaglio \& Katz, 2001). Entrepreneurial alertness leads to entrepreneurial intention. There are several pieces of research verifying the effects of entrepreneurial alertness on entrepreneurial intention. Entrepreneurial alertness affects students' intention to be entrepreneurs (Kristiansen \& Indarti, 2004; Astuti \& Martdianty, 2012). Kaish \& Gilad (1991) in Busenitz (1996) also stated that entrepreneurial alertness causes entrepreneurs to explore and take advantage of new business opportunities. They proposed that entrepreneurs heighten their alertness to opportunities by using information to assess the potential of business opportunities. Gaglio \& Katz (2001) revealed that the ability of an entrepreneur to recognize opportunities is stimulated by enhanced entrepreneurial alertness. Opportunity identification is at the core of entrepreneurial ability. Entrepreneurs' capability to identify opportunities affects the development of new ventures. Entrepreneurial alertness facilitates the identification of emerging markets. Tang, Kacmar \& Busenitz (2012) introduced a model featuring three distinct elements of alertness: scanning and searching, association and connection, and evaluation and judgment. The model proposed high levels of alertness to increase the possibility of identifying opportunities.

\section{RESEARCH FRAMEWORK}

The research framework below (Figure 1) relies on previous studies by Din et al. (2015), Karabulut (2016) and Yildirim, Çakir, \& Askun (2016). This research examines the dimension of personality traits including: internal locus of control, the need for achievement, risk tolerance and entrepreneurial alertness as independent variables. Entrepreneurial behavior is used as a dependent variable mediated by entrepreneurial intention.

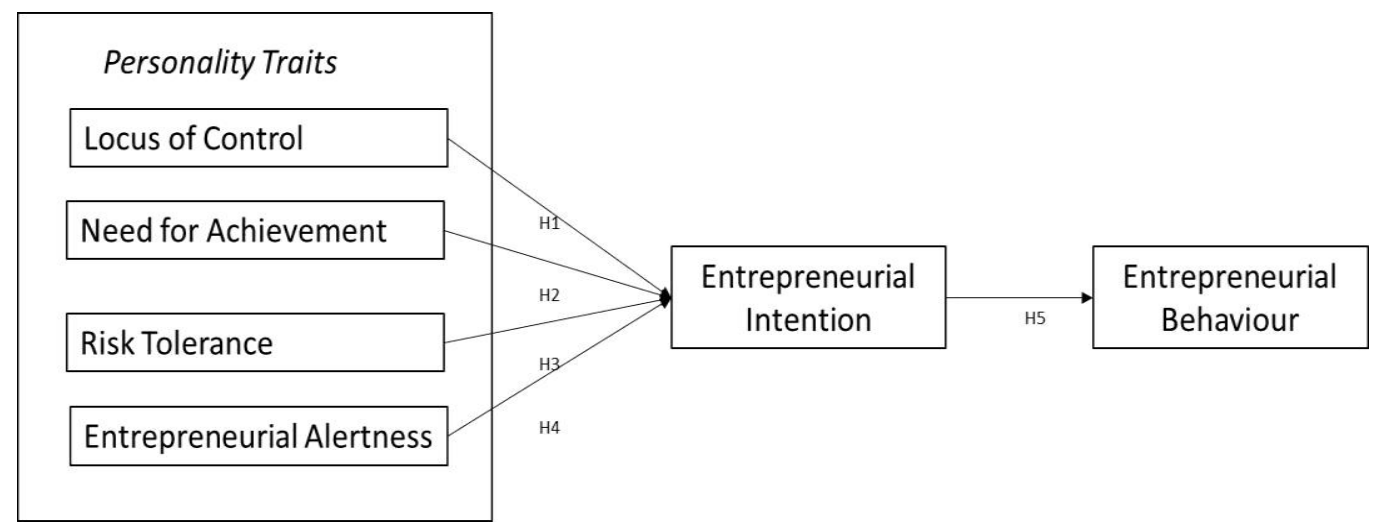

Figure 1. Research Framework 
H1: Locus of control has significant effects on entrepreneurial intention

$\mathrm{H} 2$ : Need for achievement has significant effects on entrepreneurial intention

H3: Risk tolerance has significant effects on entrepreneurial intention

H4: Entrepreneurial alertness has significant effects on entrepreneurial intention

H5: Entrepreneurial intention has significant effects on entrepreneurial behaviour

\section{RESEARCH METHOD}

This research employed quantitative methods to conduct statistical hypothesis testing. The research population consisted of Indonesian undergraduates who had previously participated in higher education entrepreneurship courses. The investigation was conducted in a private university located in Bekasi, West Java, Indonesia which has consistently been involved in developing entrepreneurial curricula. The researcher used statistical rules to calculate the size of the research sample. "The sample size classification is as follows: 100 samples - 'poor', 200 samples - 'fair', 300 samples - 'good', 500 samples - 'very good' and 1000 samples 'excellent"'(Malhotra, 2010; Permatasari \& Kuswadi, 2017). Therefore, in order to achieve a robust research sample, the researchers decided to include 300 respondents in the survey.

\section{A. Research Instrument, Data Collection and Measurement}

This study utilised questionnaires as the data collection instrument which was adopted from previous studies by Din, Anuar \& Usman (2015) and Karabulut (2016) et al. (2016) which were distributed by both online and offline means. A Likert scale was used as the form of measurement in the questionnaire. Given the scale of $1-$ 7, within which 1 represented "strongly disagree" and 7 "strongly agree", the respondents were expected to be more thoughtful in providing answers, with possible misinterpretation of the mid-point eliminated.

\section{B. Data Analysis}

Data analysis incorporated the use of structural equation modeling (SEM) to process the data and obtain the results. "SEM is a statistical technique that allows the simultaneous testing of a series of complex relationships" (Kline, 2010; Permatasari \& Kuswadi, 2017). Structural equation modeling is different to other multivariate analysis techniques. SEM only uses input data in the form of a variant/covariant matrix which has the advantage of providing a comparison between different populations. The method used was that of Maximum Likelihood (ML) which requires a minimum sample of 100 and one no greater than 400-500 because research populations falling outside these dimensions will produce a compromised Goodness-of-Fit.

\section{Statistical Analysis}

\section{A. Descriptive Statistics}

The research featured 312 respondents, all of whom were final year students following entrepreneurship courses at a Bekasi-based private university. The demographic profiles of the respondents were analysed from the perspectives of age, gender and faculty (Table 2). The results showed that $46 \%$ were male and $54 \%$ were female. The majority of respondents (72\%) fell within the 21-22 years old age range and were drawn from various study backgrounds. This research classified respondents on the basis of their affiliation to one of three faculties, namely: Business Studies, Social Sciences and Engineering. The majority of the respondents (56\%) were drawn from the Faculty of Business Studies consisting of three study programs: Business Administration, Accounting and Management, while the other students attended the Faculties of Social Science and Engineering - at $24 \%$ and $20 \%$ respectively. 
Table 2. Demographic Profiles

\begin{tabular}{llcc}
\hline & Demographic Profiles & Sum & $\%$ \\
\hline \multirow{2}{*}{ Gender } & Male & 46 & 46 \\
& Female & 54 & 54 \\
& <19 years & 4 & 4 \\
Age & 19-20 years & 11 & 11 \\
& 21-22 years & 72 & 72 \\
\multirow{2}{*}{ Faculty/Study Program } & $>23$ years & 13 & 13 \\
\multirow{3}{*}{ Business } & & & \\
& Business Administration & 21 & \\
& Accounting & 18 & 56 \\
Social & Management & 17 & \\
& International Relation & 17 & \\
\multirow{2}{*}{ Engineering } & Communication & 5 & 24 \\
& Law & 2 & \\
\hline
\end{tabular}

\section{B. Validity and Reliability Test Result}

The researcher used statistical software to calculate the construct validity which informs users of the effectiveness of the test within a particular situation (Heffner, 2017). There are five measurements used in factor analysis. First, KMO in SPSS should possess a value of more than 0,5.Second, the Barlett test, the significance of which must be less than 0,05 . Third, Eigen values which optimally exceed 1,0. Fourth, the communalities measurement values which should be higher than 0,5 . The last consists of factor loading minimums that should have a value between 0,3 and 0,4 , but are expected to have a value greater than 0,5 . The reliability test employed Cronbach's alpha whose coefficient can be employed as the measurement tool to assess reliability. Moreover, a Cronbach's alpha scores higher than 0,6 can be regarded as an indication of reliability. The contents of Table 3 confirm that all questions passed this particular test.

Table 3. Validity and Reliability Test Results

\begin{tabular}{clccc}
\hline No & \multicolumn{1}{c}{ Variables } & Number of Items & Cronbach's alpha & KMO \\
\hline 1 & Locus of Control & 5 & 0,656 & 0,967 \\
2 & Need for Achievement & 18 & 0,965 & 0,922 \\
3 & Risk Tolerance & 7 & 0,902 & 0,967 \\
4 & Entrepreneurial Alertness & 10 & 0,971 & 0,967 \\
5 & Entrepreneurial Intention & 6 & 0,960 & 0,922 \\
6 & Entrepreneurial Behaviour & 10 & 0,974 & 0,967 \\
\hline
\end{tabular}

\section{SEM Model Fit}

Within this research, the Structural Equation Modeling (SEM) analysis, conducted using statistical software (Appendix A), showed that the data fitted all dimensions being tested and that the result was proven to be qualified. The CMIN value was shown to be 2,422, while the GFI and AGFI values were 0,729 and 0,692 respectively. The IFI, TLI, and CFI values fell below 0,950 at 0,900, 0,890, and 0,899 (Table 4.4c). Finally, the RMSEA recorded a value of 0,068 which was below the criteria of 0,080 . On the other hand, the GFI and AGFI values stood at 0,729 and 0,692 . The IFI, TLI and CFI values were below 0,950 at $0,900,0,890$, and 0,899 . Finally, the RMSEA value was 0,068 which was below the criteria of 0,080. From the statistical analysis, it can 
be concluded that the model proposed in this research possesses a good fit and feasibility proven by hypothesis testing (Table 4).

Table 4. SEM Model Fit Test Results

\begin{tabular}{lcc}
\hline \multicolumn{1}{c}{ Model Fit Criteria } & Cut of Criteria & Interpretation \\
\hline Chi-square & 0,005 & Significant \\
Root Mean Square Error of & $0,05 \leq$ RMSEA $\leq 0,1$ & Good Fit \\
Approximation (RMSEA) & $0 \leq \mathrm{x} \leq 1$ & Good Fit \\
Tucker Lewis Index (TLI) & $0 \leq \mathrm{x} \leq 1$ & Good Fit \\
Comparative fit Index (CFI) & $0 \leq \mathrm{x} \leq 1$ & Good Fit \\
Inferential Fix Index (IFI) & $2,0<\mathrm{CMIN} / \mathrm{DF} \leq 5,00$ & Good Fit \\
\hline
\end{tabular}

\section{Hypothesis testing}

The hypothesis testing results show that of the five hypothesis, four ( $\mathrm{H} 2, \mathrm{H} 3, \mathrm{H} 4, \mathrm{H} 5)$ are proven to be supported, while one (H1) is rejected. From the analysis contained in Table 5, this research suggests that personality traits such as the need for achievement, tolerance of risk and entrepreneurial awareness exert significant influence on entrepreneurial intention. Parallel to that statement, entrepreneurial intention has also been proven to have significant effects on entrepreneurial behavior. On the other hand, the locus of control produces no significant effects on entrepreneurial intention. It can be seen from Table 5, that the P Value of H1 is 0,791 which is greater than 0,05 , while the Critical Ratio (C.R) $-0,265$ is lower than 2,0 as the standard critical ratio.

Table 5. Hypothesis Testing

\begin{tabular}{lccc}
\hline \multicolumn{1}{c}{ Hypothesis } & C.R. & Sig. P & Conclusion \\
\hline $\begin{array}{l}\text { H1 : Locus of control } \rightarrow \\
\text { Entrepreneurial Intention }\end{array}$ & $-2,265$ & 0,791 & Rejected \\
H2 : Need for achievement $\rightarrow$ & & $* * *$ & Accepted \\
entrepreneurial intention & 3,334 & & \\
H3 : Risk tolerance $\rightarrow$ & & $* * *$ & Accepted \\
Entrepreneurial Intention & 8,461 & & \\
H4 : Entrepreneurial alertness $\rightarrow$ & & $* * *$ & Accepted \\
$\begin{array}{l}\text { Entrepreneurial Intention } \\
\text { H5 : Entrepreneurial Intention } \rightarrow\end{array}$ & 12,779 & & \\
Entrepreneurial Behaviour & & $* * *$ & Accepted \\
\hline
\end{tabular}

This research also tested the hypothesis within faculties such as: business studies, social sciences \& humanities and engineering. Hypothesis testing results show that, within the Faculty of Business Studies, of the five hypothesis, three of them $(\mathrm{H} 3, \mathrm{H} 4, \mathrm{H} 5)$ were proven to be supported and two $(\mathrm{H} 1$ and $\mathrm{H} 2)$ were rejected. These results were repeated within the Faculty of Social Sciences and Humanities, while within the Faculty of Engineering, of five hypothesis, only two were supported (H4 \& H5) with the other three being rejected. From the analysis shown in Table 6, personality traits such as entrepreneurial alertness have significant impact on entrepreneurial intention towards entrepreneurial behaviour, while tolerance of risk exerts significant influence on entrepreneurial intention for students within the Faculties of Business and Social studies. On the other hand, 
the locus of control and need for achievement have no significant effects on entrepreneurial intention (it can be shown from Table 6 that $\mathrm{P}$ Values of $\mathrm{H} 1$ and $\mathrm{H} 2$ have more than 0,05 ).

Table 6. Regression Weight Comparison among Faculties

\begin{tabular}{lllcccccc}
\hline \multirow{2}{*}{ Regression Weights } & \multicolumn{2}{c}{ Business } & \multicolumn{2}{c}{ Social Studies } & \multicolumn{2}{c}{ Engineering } \\
& & & C.R & P-Value & C.R & P-Value & C.R & P-Value \\
\hline EI & $<---$ & LOC & $-1,423$ & .155 & $-0,768$ & .442 & -0.813 & .416 \\
EI & $<---$ & NOA & 1,331 & .183 & 2,708 & .007 & 1.977 & .048 \\
EI & $<---$ & RT & 3,894 & $* * *$ & 5,188 & $* * *$ & 2.526 & .012 \\
EI & $<---$ & EA & 9,401 & $* * *$ & 3,192 & .001 & 6.431 & $* * *$ \\
EB & $<---$ & EI & 11,01 & $* * *$ & 6,033 & $* * *$ & 7.293 & $* * *$ \\
\hline
\end{tabular}

\section{RESUlTS AND DisCUSSION}

The research reported here successfully evaluates the entrepreneurship education programs implemented by a private university in Bekasi, Indonesia that has been developing entrepreneurship curricula for more than five years. The design of such programs adjusted entrepreneurship personality traits to support entrepreneurial intention and behavior. The degrees of fit test results confirm the research model to be appropriate. This study re-examines the report by Davidsson \& Gordon (2012) in Hayes \& Richmond (2017) that, “... only seven of the fifty-three entrepreneurial studies examined have a positive impact on entrepreneurial education". On the other hand, based on the findings, it can be concluded that the entrepreneurial education programs delivered in a private university in Bekasi, Indonesia have a significant effect on students' entrepreneurial ambitions and behavior. Busato et al. (1998) in Hayes \& Richmond (2017) also mention that matching learning styles and personality traits will improve entrepreneurial outcomes. The results of hypothesis testing also showed that the entrepreneurial intention of students in their final year was proven to have a significant effect on entrepreneurial behavior. This finding is also related to that of Potishuk \& Kratzer (2017) which stated that, "Educational programs in entrepreneurship positively affect entrepreneurial intention". Entrepreneurial intention is influenced by personality traits such as the need for achievement, risk tolerance and entrepreneurial alertness. The last, from the coefficient of the path, it can be concluded that the variable exerting the greatest influence on entrepreneurial intention is that of entrepreneurial alertness. Potishuk \& Kratzer's (2017) findings show that role models increase "... entrepreneurial intention as long as contact with professionals is inspiring for students who, in turn, may easily adopt the behavior of the role models". Hayes \& Richmond (2017) also stated in their previous research that universities can assist students in becoming self-aware of their unique entrepreneurial traits and facilitating the development of skills required for future success. This being a measurement approach, Ghina et.al. (2015) stated that, "The measures that are used for entrepreneurial education assessment must relate to the entrepreneurial program's goals". Entrepreneurial orientation is key success for organization (Andiningtyas \& Nugroho, 2014). Therefore, universities or higher education institutions should re-think the design of entrepreneurship education programs with regard to the necessity for structure, curricula and teaching methods.

\section{CONCLUSION AND RECOMMENDATION}

This study indicated that entrepreneurship education programs developed by private universities need to improve further with regard to personality traits within the locus of control. The findings suggest that the locus of control exerts no influence on student entrepreneurial intention. This was also confirmed by analysis within faculties that achievement and risk management need to be more prominent in the development of entrepreneurial education, especially within Faculties of Engineering. Therefore, to improve the quality of entrepreneurship education programs within higher education institutions there is a need to focus learning activity programs within faculties on personality traits. For the future, this research can be expand to another university who has entrepreneurship study program as their one compulsory course. Moreover, the researcher can identify the difference intention among students and increase their entrepreneurial behaviour after graduation. 


\section{REFERENCES}

Ambad, S N.A., \& Damit, D.H.D. (2015). Determinants of entrepreneurial intention among undergraduate students in Malaysia. $5^{\text {th }}$ International Conference on Marketing and Retailing-Procedia Economics and Finance, 37, 108 - 114.

Andinintyas, I., \& Nugroho, R.L (2014). Pengaruh orientasi kewirausahaan terhadap kinerja perusahaan kecil. Jurnal Manajemen Indonesia, 14, 37-46.

Astuti, R.D., \& Martdianty, F. (2012). Students' entrepreneurial intentions by using theory of planned behavior. South East Asian Journal of Management, 6, 100-143

Brandstätter, Hermann. (2011). Personality aspects of entrepreneurship: A look at five meta-analyses. Personality and Individual Differences, 51,.222-230.

Busenitz, L.W. (1996). Research on entrepreneurial alertness. Journal of Small Business Management, 34, 3544.

Comfrey, A. L., \& Lee, H. B. (1992). A First Course in Factor Analysis. Hillsdale, NJ: Lawrence Erlbaum Associates.

Din, B, Anuar, A.R., \& Usman, M. (2016). The effectiveness of the entrepreneurship education program in upgrading entrepreneurial skills among public university students. Procedia - Social and Behavioral Sciences, 224, 117 - 123.

Gaglio, C.M., \& Katz, J.A. (2001). The psychological basis of opportunity identification: Entrepreneurial alertness. Small Business Economics, 16, 95-111.

Ghina, A., Simatupang, T.M., \& Gustomo, A. (2013). Building a Systematic Framework for Entrepreneurship Education. Journal of Entrepreneurship Education, 18, 73-98.

Ghina, A, Simatupang, T.M., \& Gustomo, A. (2017). The relevancy of graduates' competencies to the effectiveness of entrepreneurship education. Journal of Entrepreneurship Education, 20, 1-24.

Global Entrepreneurship and Development Index. (2017). Annual Report GEDI 2017. Official website: https://thegedi.org/global-entrepreneurship-and-development-index/

Hayes, D., \& Richmond, A.W. (2017). Using an online assessment to examine entrepreneurship student traits and to measure and improve the impact of entrepreneurship education. Journal of Entrepreneurship Education, 20, 88-107.

Karabulut, A.T. (2016). Personality Traits on Entrepreneurial Intention. Procedia - Social and Behavioral Sciences, 229, 12-21.

Kassean, H., Vanevenhoven, J., Liguori, E., \& Winkel, D. E. (2015). Entrepreneurship education: a need for reflection, real-world experience and action. International Journal of Entrepreneurial Behavior and Research, 21, 690-708

Khan, K. (2013). Empirical analysis of entrepreneurial intentions. A case of Kabul based business students, Afghanistan. International. Journal of Information Business and Management, 5, 184-197.

Kim, H. W., Sumeet, G., \& Li, H. (2005). Different effects of perceived price and risk on purchase intention for potential and repeat customers. Expert Systems with Applications, 39, 594-610.

Kirkley, W.W. (2016). Creating ventures: decision factors in new venture creation, Asia Pacific Journal of Innovation and Entrepreneurship, 10,.151-167.

Kline, R. B. (2010). Principles and practice of structural equation modeling (3rd ed). New York: Guilford Press.

Koe, W.L., Omar, R., \& Sa'ari, J.R. (2015). Factors influencing propensity to sustainable entrepreneurship of SMEs in Malaysia. Procedia - Social and Behavioral Sciences, 172, 570-577.

Koe, W.L., Sa'ari, J.R., Majid, I.A., \& Ismail. K. (2012). Determinants of entrepreneurial intention among millennial generation. Procedia - Social and Behavioral Sciences, 40, 197-208.

Kristiansen, S., \& Indarti, N. (2004). Entrepreneurial intention among Indonesian and Norwegian students, Journal of Enterprising Culture, 12, .55-78.

Küttim, M., Kallaste, M., Venesaar, U., Kiis, A. (2014). Entrepreneurship education at university level and students' entrepreneurial intentions. Procedia - Social and Behavioral Sciences, 110, 658 - 668.

Malhotra, N. (2010). Review of Marketing Research. Singapore; RMR.

McClelland, D.C. (1965). Achievement motivation can be developed, Harvard Business Review, 43, 6-24.

Permatasari, A., \& Kuswadi, E. (2017). The impact of social media on consumers purchase intention: A Study of ecommerce sites in Jakarta, Indonesia. Review of Integrative Business and Economics Research, 6, 321-335.

Potishuk, V., \& Kratzer, J. (2017). Factors affecting entrepreneurial intentions and entrepreneurial attitudes in higher education. Journal of Entrepreneurship Education, 20, 25-44. 
Rauch, A., \& Frese, M. (2007). Let's put the person back into entrepreneurship research: A meta-analysis on the relationship between business owners' personality traits, business creation, and success. European Journal of Workand Organizational Psychology, 16, 353-385.

Sekaran, U., \& Bougie, R. (2009). Research Methods For Business A Skill Building Approach, Chichester: John Wiley \& Sons Ltd, England.

Storr, V.H. \& John, A. (2011). The determinants of entrepreneurial alertness and the characteristics of successful entrepreneurs. The Annual Proceedings of the Wealth and Well-Being of Nations, 87-107.

Tang, J., Kacmar, M., \& Busenitz, L. (2012) Entrepreneurial alertness in the pursuit of new opportunities. Journal of Business Venturing, 27, 77-94.

Wang, C.K., \& Wong, P.K. (2004). Entrepreneurial interest of university students in Singapore. Technovation, 24, 163-72.

Yu, Tony Fu-Lai (2001) Entrepreneurial Alertness and Discovery. The Review of Austrian Economics, 14, 4763

Yurtkoru, E.S,. Kuşcu. Z.K,. \& Doğanay ${ }^{a}$,A. (2014). Exploring the antecedents of entrepreneurial intention on Turkish university students. Procedia - Social and Behavioral Sciences, 150, 841-850.

Yildirim, N., Çakir, Ö., \& Askun, O. (2016). Ready to dare? A case study on the entrepreneurial intentions of business and engineering students in Turkey. Procedia - Social and Behavioral Sciences, 229, 277 - 288. 
Appendix A

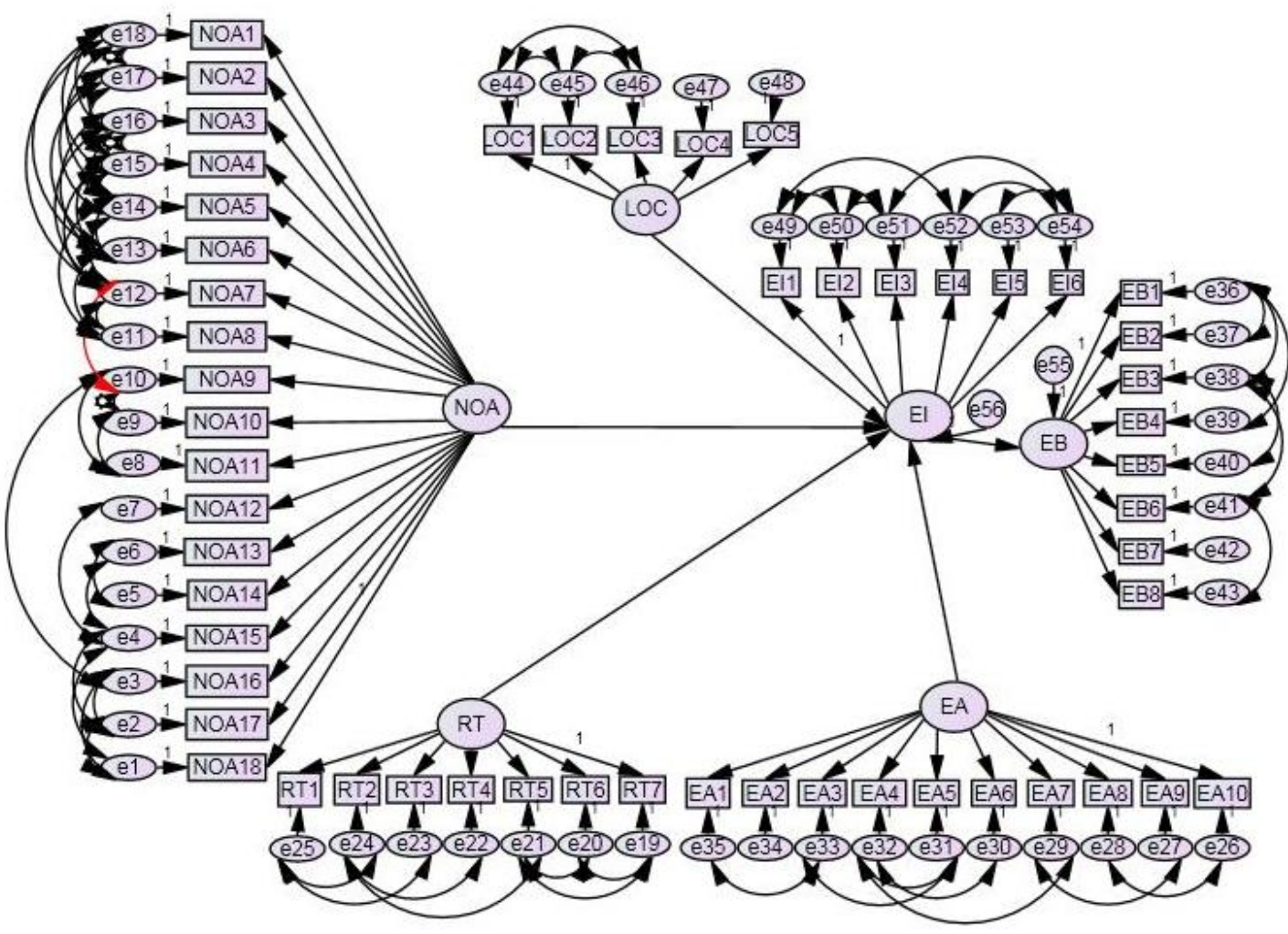

